\title{
Upregulation of extraneuronal TRPV1 expression in chronic rhinosinusitis with nasal polyps*
}

\author{
Eszter Tóth', Tamás Tornóczky², Józsefné Kneif², Anikó Perkecz³ , Krisztián \\ Katona² , Zalán Piski ${ }^{4}$, Ágnes Kemény ${ }^{3}$, Imre Gerlinger ${ }^{4}$, János Szolcsányi ${ }^{3}$, \\ József Kun ${ }^{\# 3,5}$, Erika Pintér $\# 3,5$ \\ 1 Department of Oto-Rhino-Laryngology Head and Neck Surgery, Hungarian Defense Forces, National Health Center, Budapest, \\ Hungary \\ 2 Department of Pathology, University of Pécs Medical School, Pécs, Hungary \\ 3 Department of Pharmacology and Pharmacotherapy, University of Pécs Medical School, Pécs, Hungary \\ 4 Department of Oto-Rhino-Laryngology, Head and Neck Surgery, University of Pécs Medical School, Pécs, Hungary \\ 5 János Szentágothai Research Center and Center for Neuroscience, University of Pécs, Pécs, Hungary
}

Rhinology 56: 3, 245-254, 2018

https://doi.org/10.4193/Rhin17.108

* Received for publication:

May 26, 2017

Accepted: January 11, 2018

" contributed equally to the manuscript

Background: Chronic rhinosinusitis (CRS) is a multifactorial upper airway disease with unclear etiology. Neuronal Transient Receptor Potential Vanilloid 1 (TRPV1) and Ankyrin 1 (TRPA1) channels have been implicated in the pathogenesis of CRS. We aimed to detect the expression of extraneuronal TRPV1 and TRPA1 receptors in nasal polyp (NP) tissue samples.

Methodology: Samples were obtained from fourty-two CRS pateints with nasal polyp and sixteen healthy controls to measure receptor gene expression by quantitative PCR, protein localization by immunohistochemistry and cytokine profile by multiplex bead immunoassay.

Results: Non-neuronal TRPV1, TRPA1 receptors were expressed in biopsy samples of NP. A population of mast cells and macrophages were immunopositive for TRPV1 and TRPA1. A fraction of plasma cells expressed TRPV1 but not TRPA1 and neither receptor was present on eosinophils. The local gene expression of extraneuronal TRPV1, TRPA1 receptors was also proven. TRPV1 mRNA levels were significantly increased in CRSwNP patients with asthma and allergic rhinitis compared to their NP counterparts.

Conclusions: Elevated TRPV1 levels in comorbid asthma and allergy may have a function in CRSwNP. Subpopulation-specific TRPV1 presence on plasma and mast cells can indicate delicate roles in regulating activation and release of inflammatory mediators.

Key words: chronic rhinosinusitis, asthma, TRPV1, TRPA1, plasma cell

\section{Introduction}

Chronic rhinosinusitis (CRS) is characterized by chronic inflammation of the sinonasal mucosa. Two clinically and phenotypically distinct groups are chronic rhinosinusitis with and without nasal polyps (CRSwNP and CRSsNP, respectively) with variants based on type of inflammation and comorbidities. Therapy resistance and recurrance are frequent in CRS. Asthma and allergy have enormous impact on its development, especially in CRSwNP: CRS is histologically characterized by inflammation and oedema of the nasal mucosa with infiltration of inflammatory cells (periglandular and stromal lymphoplasmocytic, polimorphonuclear, mast cell) and eosinophilia. Neurogenic inflammation in the upper airway mucosa plays a pivotal role via neuropeptides released upon sensory nerve stimulation leading to the so called "nasal symptoms" (1-4).

Transient Receptor Potencial Vanilloid 1 (TRPV1) is expressed on primary sensory neurons, such as those innervating the human nasal mucosa ${ }^{(5,6)}$. TRPV1 is a heat and noxious stimuli sensor mediating neurogenic inflammation, pain sensation, itch, sneezing and nasal secretion ${ }^{(7-9)}$. TRPV1 has been implicated in vasomotor, gustatory and idiopathic rhinitis ${ }^{(10-12)}$. The potent TRPV1 agonist capsaicin (the pungent principle in hot pepper) 
selectively excites and, in repeated high dosis, desensitizes or even reversibly damages a subpopulation of sensory nerve fiber terminals ${ }^{(13)}$. Capsaicin desensitization/denervation has been demonstrated to improve nasal symptoms in non-allergic rhinitis and CRS (11,14-20).

More recently, TRPV1 receptors have been identified in nonneuronal cells, as well (epidermis, epithelium of various organs, immune system) (21-26). In human nasal mucosa, non-neuronal TRPV1 has been found on normal epithelium ${ }^{(8)}$, submucosal glands ${ }^{(5)}$ and CD4+ T-lymphocytes ${ }^{(27)}$. The structurally and functionally similar Transient Receptor Potential Ankyrin 1 (TRPA1) can be activated by noxious cold and environmental irritants. TRPA1 has a prominent sensor role in airway irritation, cough reflex and presumably in cold dry air responses in non-allergic rhinitis ${ }^{(28-30)}$. Functional extraneuronal TRPA 1 channels are also present in the normal human nasal epithelium ${ }^{(8)}$. Lately, it has been shown that non-neuronal TRPV1, TRPA1 are upregulated in oral lichen planus ${ }^{(31,32)}$.

TRPV1, TRPA1 receptors have been described on sensory nerves of the nasal mucosa to have pivotal roles in mediating neurogenic inflammation, hyperreactivity and histamine-induced itch ${ }^{(10,33,34)}$. However, non-neuronal TRP functions have not been fully elucidated yet. Our aim was to detect the presence and expression change of extraneuronal TRPV1 and TRPA 1 channels along with key cytokines in CRSwNP compared to healthy nasal mucosa.

\section{Materials and methods}

Ethical approval and consent

Written informed consent was obtained from all patients prior to the process. The study was approved by the Regional Research Ethics Comitte of the University of Pécs Medical School (no. 3746.316-3040/2010).

\section{Patients}

Healthy control subjects and patients with CRSwNP were recruited from the Department of Otolarnygology Head-and Neck Surgery, Universitiy of Pécs (Pécs, Hungary). Nasal polyp (NP) samples were obtained during routine endonasal sinus surgery from 33 patient suffering from CRSwNP. Diagnosis was based on clinical signs, endoscopical findings and CT scans according to the criteria of CRS as defined by the European Position Paper on Rhinosinusitis and Nasal Polyps ${ }^{(35)}$. All patients used long-term intranasal corticosteroid (INCS) treatment but it was found to be ineffective. Patients ranged from 18-70 years in age, 17 females and 16 males, and divided into subgroups according to comorbidities as appeared in the clinical history: allergic rhinitis and/ or asthma. Allergic rhinitis was based on positive prick test and clinical signs; asthma on the evidence of the pulmonologist. 10 control samples were obtained from healthy subjects without history of any inflammatory upper airway or sinonasal disease, 4
Table 1. Patient characteristics of patient group no. 1.

\begin{tabular}{|lccccc|}
$\begin{array}{l}\text { Patient } \\
\text { group \#1 }\end{array}$ & Number & $\begin{array}{c}\text { Mean } \\
\text { age }\end{array}$ & Female & Male & Smoking \\
\hline NP only & 14 & 50.3 & 5 & 9 & 5 \\
\hline NP+AR & 7 & 46.0 & 3 & 4 & 3 \\
\hline NP+As & 2 & 50.5 & 1 & 1 & 2 \\
\hline NP+As+AR & 10 & 57.3 & 8 & 2 & 1 \\
\hline Total CRS & 33 & 51.0 & 17 & 16 & 10 \\
\hline $\begin{array}{l}\text { Healthy } \\
\text { control }\end{array}$ & 10 & 45.0 & 4 & 6 & 0 \\
\hline
\end{tabular}

NP only = nasal polyposis without asthma and allergic rhinits, NP + As $=$ nasal polyposis with asthma; $\mathrm{NP}+\mathrm{AR}=$ nasal polyposis with allergic rhinits; NP + As + AR = nasal polyposis with both asthma and allergic rhinitis.

Table 2. Patient characteristics of patient group no. 2 .

\begin{tabular}{lcccc} 
Patient group \#2 & Number & Mean age & Female & Male \\
\hline Healthy control & 6 & 48,2 & 3 & 3 \\
NP+AS & 9 & 59,1 & 4 & 5 \\
Total & 17 & 53,6 & 7 & 8
\end{tabular}

$\mathrm{NP}+\mathrm{AS}=$ nasal polyposis with asthma.

females, 6 males. Samples were taken from the inferior turbinate during routine septal surgery or turbinotomy. In the second part of the study we further examined 9 new polyp samples obtained from NP patients only from the subgroup of asthma and 6 controls. Patient characteristics are displayed in Table 1 and 2 . Based on the histopathological reports two CRS endotypes were observed: the inflammatory and the remodeling dominant type, corresponding to the literature ${ }^{(36)}$. In our study, 40 patients had inflammatory type of pathologies with eosinophil predominance and 2 had remodeling dominant histology with fibroblasts.

\section{Tissue}

Excised tissue samples were cut into three pieces. One part was put into RNAlater (cat. no. R0901, Sigma-Aldrich, St. Louis, $\mathrm{MI}$, USA) and one part was prepared for fresh frozen sample and stored in $-80^{\circ} \mathrm{C}$. The third part was fixed in $4 \%$ paraformaldehyde and embedded in paraffin for immunohistochemical examination.

\section{Immunohistochemistry}

Tissue samples were evaluated for mast cells, polimorphonuclear leukocytes (PMN), eosinophils (EO), lymphocytes and plasma cells with methylated Giemsa (M\&G) staining. Deparaffinized 
and rehydrated tissue sections were incubated in methylating solution ( $99 \mathrm{ml}$ methanol, $1 \mathrm{ml} \mathrm{36 \%} \mathrm{hydrochloric} \mathrm{acid)} \mathrm{for} 20$ min at $56{ }^{\circ} \mathrm{C}$ followed by Giemsa staining solution (20 ml Giemsa stain, Central Clinical Pharmacy, Medical School, University

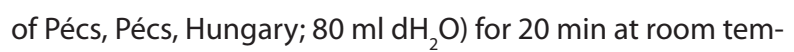
perature. Differentiating solution $(200 \mu \mathrm{lcc}$. acetic acid in 100 $\mathrm{ml} \mathrm{dH}_{2} \mathrm{O}$ ) was applied then slides were rinsed in $96 \%$ ethanol and washed in xylol for $3 \times 5 \mathrm{~min}$. Sections were coverslipped using Pertex mounting medium (Histolab Products AB, Västra Frölunda, Sweden). Slides were scanned using the Pannoramic Desk instrument (3D Histech Ltd., Budapest, Hungary). Cover slips were removed $\left(x y l o l\right.$ at $56^{\circ} \mathrm{C}$ until detachment followed by $5 \mathrm{~min}$ in $96 \%$ ethanol). Slides were immunostained using the Leica Bond Max automated stainer (Leica Biosystems, Wetzlar, Germany) in the following main steps. Slides were rinsed in $\mathrm{dH}_{2} \mathrm{O}$ followed by antigen retrieval (Bond Epitope Retrieval Solution 1, Leica Biosystems, Wetzlar, Germany) at pH 6.00 for 20 min. Slides were immunostained by either anti-TRPV1 (1:300; cat. no. GP14100, Neuromics, Edina, MN, USA) or anti-TRPA1 (1:250; cat. no. ARP35205-P050; Aviva Systems Biology, San Diego, CA, USA) rabbit polyclonal primary antibody for 15 minutes. Slides were incubated with the Bond Polymer Refine Detection Kit at $37^{\circ} \mathrm{C}$ for 20 min with anti-rabbit Poly-HRP-lgG secondary antibody with subsequent chromogenic development using diaminobenzidine tetrahydrochloride hydrate (DAB) for $10 \mathrm{~min}$ and hematoxylin nuclear staining for 5 min (all components part of the Bond Polymer Refine Detection Kit, Leica Biosystems, Wetzlar, Germany) followed by bluing for 5 minutes and rehydration by $3 \times 5 \mathrm{~min}$ in $96 \%$ alcohol and $3 \times 5 \mathrm{~min}$ in xylol. Cover slips were mounted again using Pertex medium (Histolab Products AB, Västra Frölunda, Sweden) and re-scanned using the Pannoramic Desk instrument and visualized by Pannoramic Viewer 1.15 software (both from 3D Histech Ltd., Budapest, Hungary). Examination of the tissue sections and identification of immunopositivity and cell morphology were performed by an expert pathologist.

\section{Luminex Multiplex Immunoassay}

The excised and frozen tissues were thawed and weighed, and homogenized (TissueLyser II bead mill system, cat. no. 85300, Qiagen, Hilden, Germany) in $450 \mu$ l Procarta Cell Lysis Buffer (Affymetrix, Santa Clara, CA, USA). Samples were centrifuged at 2000xg for $20 \mathrm{~min}$. at $4{ }^{\circ} \mathrm{C}$ than supernatants were collected and used for further analysis. Procarta Immunoassay (Affymetrix, Santa Clara, CA, USA) using Luminex technology was performed to determine the concentration of interferon gamma (IFN $\gamma$ ) interleukin 4 (IL-4), interleukin 5 (IL-5) and interleukin 8 (IL-8, CXCL8) cytokines in the samples. The experiment was performed according to the manufacturer's instructions. Following previous optimizations, all samples were tested undiluted in a blind-fashion. Luminex 100 device was used for the immunoas- say and Luminex 100 IS software (both from Luminex Corp., Austin, TX, USA) for the analysis of bead median fluorescence intensity. All tests were run in duplicates. $25 \mu$ volume of each sample, control, or standard was added to a 96-well plate (provided with the kit) containing antibody coated fluorescent beads. Biotinylated secondary antibodies and streptavidin-PE were added to the plate with alternate incubation and washing steps. After the last washing step, $120 \mu$ l of reading buffer was added to the wells; the plate was incubated and read on the Luminex100 array reader, using a five-PL regression curve to plot the standard curve. Data were analyzed using the MasterPlex software. Results are given as pg/g wet tissue.

\section{Quantitative Real-Time RT-PCR (qRT-PCR)}

Purification of total RNA was carried out according to the TRI Reagent manufacturer's (Molecular Research Center, Inc., Cincinnati, $\mathrm{OH}, \mathrm{USA}$ ) protocol up to the step of acquiring the aqueous phase. Briefly, tissue samples were homogenized in 1 $\mathrm{ml}$ of TRI Reagent, and then, $200 \mu$ l of bromo-chloro-propane (Molecular Research Center, Inc.) was added. RNA was purified from the aqueous phase using the Direct-zol RNA MiniPrep kit (cat. no. R2052; Zymo Research, Irvine, CA, USA) according to the manufacturer's protocol. Briefly, $400 \mu \mathrm{l}$ of the aqueous phase was mixed with $400 \mu \mathrm{l}$ absolute ethanol, the mixture was loaded into the column, washed, and the RNA was eluted in $50 \mu \mathrm{l}$ of RNase-free water. The quantity and purity of the extracted RNA was assessed on Nanodrop ND-1000 Spectrophotometer V3.5 (Nano-Drop Technologies, Inc., Wilmington, DE, USA). 500 ng of total RNA was reverse transcribed using Maxima First Strand cDNA Synthesis Kit (cat. no. K1642, ThermoScientific, Santa Clara, CA, USA) according to the manufacturer's instructions. qRT-PCR was performed on a Stratagene Mx3000P qPCR System (Agilent Technologies, Santa Clara, CA, USA). PCR amplification was performed using SensiFast Probe/SYBR Lo-ROX Kit (cat. nos BIO-84020/BIO-94020) and primers and probes described in detail in Supplementary Table 1. Primers for IgE transcripts were adapted from Wood et al. ${ }^{(37)}$. Transcripts of the reference genes glyceraldehyde 3-phosphate dehydrogenase (GAPDH), hypoxanthine phosphoribosyltransferase 1 (HPRT1), beta-actin and beta-glucuronidase (GUSB) were detected in all samples. GAPDH and HPRT1 were eventually chosen as internal controls, the geometric mean of their $C_{q}$ values were calculated. Primers of similar efficiencies were used and $2^{\Delta \Delta c q}$ fold change values were calculated.

\section{Statistical analysis}

Unpaired t-test or one-way ANOVA with Tukey's multiple comparisons test on log2 transformed mRNA fold change data, and Mann-Whitney test or Kruskall-Wallis with Dunn's multiple comparisons test on cytokine protein data were performed using GraphPad Prism 5.02 for Windows (GraphPad Software, 


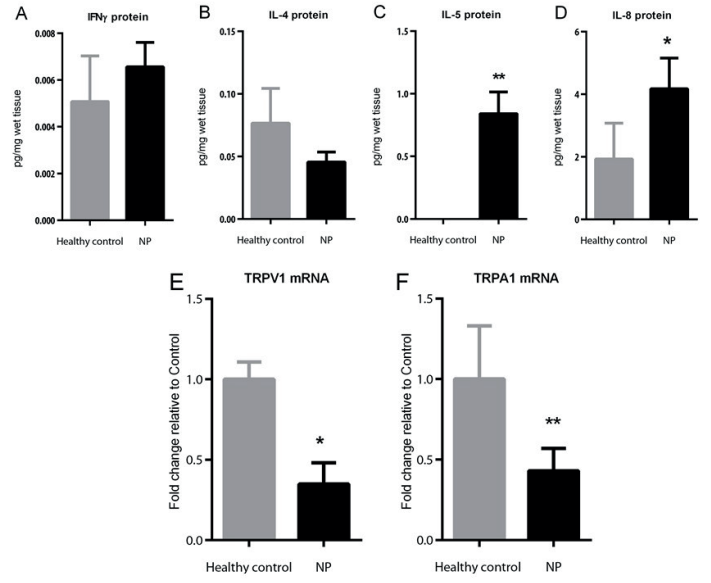

Figure 1. Cytokine protein (A-D) and TRP mRNA (E-F) levels in nasal tissue homogenates of healthy control and CRSwNP patients in patient group 1. NP: CRSwNP; IL: interleukin; IFNY: interferon gamma. Mann-Whitney test on cytokine protein data and unpaired t-test on mRNA data was applied. ${ }^{*} p<0.05 ;{ }^{* *} p<0.01$ vs. healthy control.

Inc., La Jolla, CA, USA). Probability values $\mathrm{P}<0.05$ were accepted as significant. Error bars represent standard error of the mean (SEM). Log2 mRNA fold change data were further analyzed by hierarchical cluster analysis then visualized in a heat map using the free web tool Morpheus (Broad Institute, Cambridge, MA, USA) ${ }^{(38)}$. Correlation analysis of log2 gene expression data was performed by biweight mid-correlation algorithm implemented in $\mathrm{R}$ 3.2.3 programming language applying bicor function of the WGCNA package ${ }^{(39)}$. Correlation coefficients ( $r$ values) were visualized in a heat map using the Morpheus web tool (38).

\section{Results}

Cytokine profile

Interleukin-4 (IL-4), IL-5, IL-8 and interferon gamma (IFNץ) protein levels were measured in nasal tissue homogenates of CRSwNP patients in group \#1 (Figure 1 A-D). IL-8 protein amounts increased significantly 2.2 fold to $4.2 \mathrm{pg} / \mathrm{mg}$ wet tissue in NP patients compared to the healthy control group. IL-5 protein was not detected in control samples. When subgroups were compared (Figure $2 \mathrm{~A}-\mathrm{D}$ ) only IL-4 was significantly altered: it elevated 2.3 fold to $0.070 \mathrm{pg} / \mathrm{mg}$ wet tissue in patients with both asthma and allergic rhinitis compared to their NP counterparts without these comorbidities.

\section{TRP MRNA expression}

Both TRPV 1 and TRPA 1 transcripts were detected in nasal polyp and normal nasal mucosa. In patient group \#1, TRPV1, TRPA1 mRNA levels of NP samples decreased significantly by 0.35 and 0.43 fold, respectively, compared to the normal mucosa (Figure $1 \mathrm{E}-\mathrm{F}$ ). When comparing TRP mRNA amounts within subgroups of CRSwNP patients, a significant elevation of TRPV1 but not

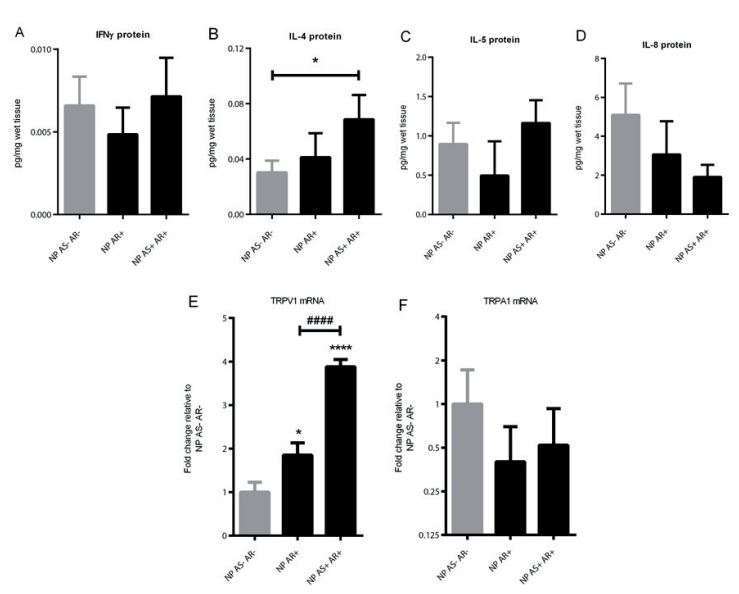

Figure 2. Cytokine protein (A-D) and TRP mRNA (E-F) levels in nasal tissue homogenates of healthy control and CRSWNP patients in patient group 1. NP: CRSwNP; AR: allergy; AS: asthma; IL: interleukin; IFNy: interferon gamma. Mann-Whitney test or Kruskall-Wallis with Dunn's multiple comparisons test on cytokine protein data and one-way ANOVA or unpaired t-test was applied on mRNA data. ${ }^{*} p<0.05$; ${ }^{* * *} p<0.0001$ vs. healthy control; \#\#\# $\mathrm{p}<0.0001$ vs. NP and AR.

TRPA1 was observed in the allergic ( 1.9 fold), and allergic + asthmatic (3.9 fold) subgroups (Figure $2 \mathrm{E}-\mathrm{F}$ ) compared to NP patients without these comorbidities. CRSwNP patients with only asthma had a 6.3 fold TRPV1 transcript increase but data were not plotted due to their low number $(n=2)$. We tested the impact of smoking on TRPV1, TRPA1 gene expression but no change was observed (data not shown). In CRSwNP patient group \#2 with asthma, TRPV1, TRPA 1 mRNA levels were decreased highly similarly to group \#1 when compared to controls without inflammatory conditions (Supplementary Figure 1).

Immunohistochemistry

Methylated Giemsa staining revealed the structure and the cellular distribution in each tissue sample (Figure 3-4). In normal nasal mucosa (Figure $3 \mathrm{~A}-\mathrm{B}$, Figure $4 \mathrm{~A}-\mathrm{B}$ ), some plasma cells, a few number of mast cells and lymphocytes were observed in the stroma. In nasal polyposis, intensive TRPV1 immunopositivity was detected in periglandular and interglandular cells around seromucuos glands which were mainly plasma cells and a population of mast cells, and, to lesser extent, other lymphocytes (Figure 3 C-D). In nasal polyps, massive infiltration of inflammatory cells, such as plasma cells, mast cells and eosinophils were observed in oedematous and swollen stroma. In the stroma of NP patients, the presence of TRPV1 positive plasma cells was the most imminent, however, only a subpopulation of plasma cells was stained with TRPV1 consistently across samples. TRPV1 expressing mast cells and macrophages were less abundant. Eosinophils and stroma cells showed no TRPV1 immunopositivity. TRPA1 immunohistochemistry (Figure 4) showed positive 

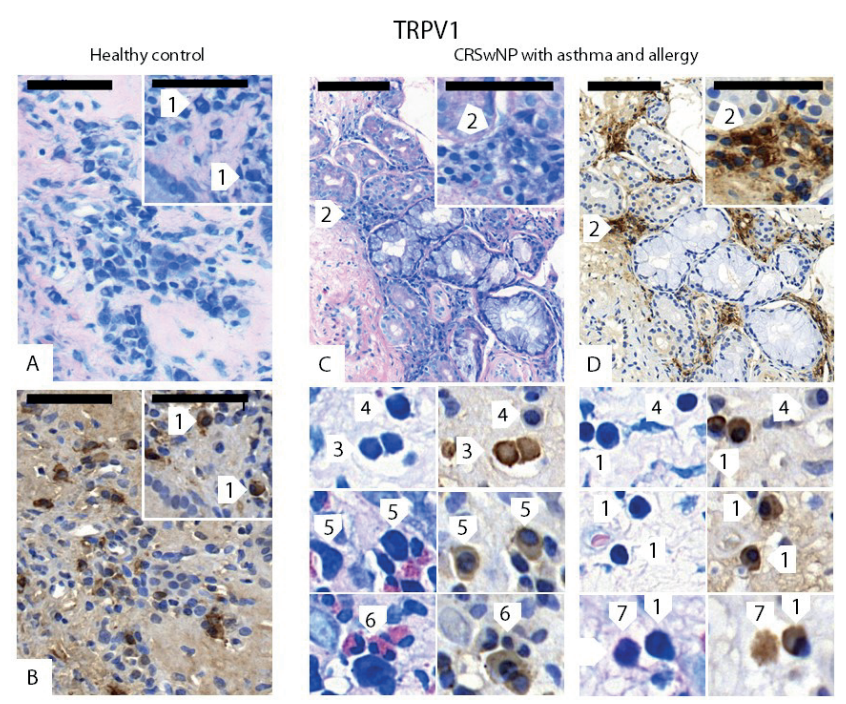

Figure 3. Paired images of Giemsa staining and TRPV1 specific immunostaining of healthy control (A, B) and CRSwNP patients with asthma and allergy (C, D with blocks of image pairs). A, B: magnification: 400x, scale bar: $50 \mu \mathrm{m}$; inserts: 600x, $50 \mu \mathrm{m}$. C, D: 200x, $100 \mu \mathrm{m}$; inserts: 600x, $50 \mu \mathrm{m}$. 1: TRPV1 positive plasma cell; 2: TRPV1 positive periglandular cells, dominantly plasma cells with a few other lymphocytes; 3: TRPV1 positive non-plasma cell lymphocytes; 4: TRPV1 negative plasma cell; 5: TRPV1 positive macrophage; 6: TRPV1 negative eosinophil granulocyte; 7: TRPV1 positive mast cell.

reaction in a population of macrophages and a population of mast cells but eosinophils were not stained. We were not able to confirm the presence of TRPA1 on plasma cells and lymphocytes. Heat map and correlation of mRNA levels

Transcripts of 15 inflammatory mediators or cell markers were further detected in patient group \#2. Nine genes were upregulated while six remained unchanged in CRSwNP with asthma which conforms to the clinical and pathologic diagnosis (Figure 5 and Supplementary Figure 2). In patient group \#2, mRNA fold changes of TRPV1, TRPA 1 and 15 inflammatory mediators/cell markers were assessed in detail. Transcript data were hierarchically clustered and expression patterns were visualized by heat map (Figure 5). Similarities between patients or gene patterns are demonstrated by dendrograms in the heat map, the length of their branches are inversely proportional to the similarity in expression patterns. Cluster analysis revealed two major inherent groups of patients corresponding to clinically healthy and CRSwNP patients with asthma. Control samples demonstrated a heterogenous gene expression pattern with relatively high levels of TRPV1, CD117 (c-Kit) and TAC4 (hemokinin-1) mRNA with most inflammatory markers unevenly distributed at a generally lower level. Nine genes implicated in Th2-driven inflammation were clustered together and were markedly upregulated in CRSwNP with asthma samples. The expression pattern of TRPV1
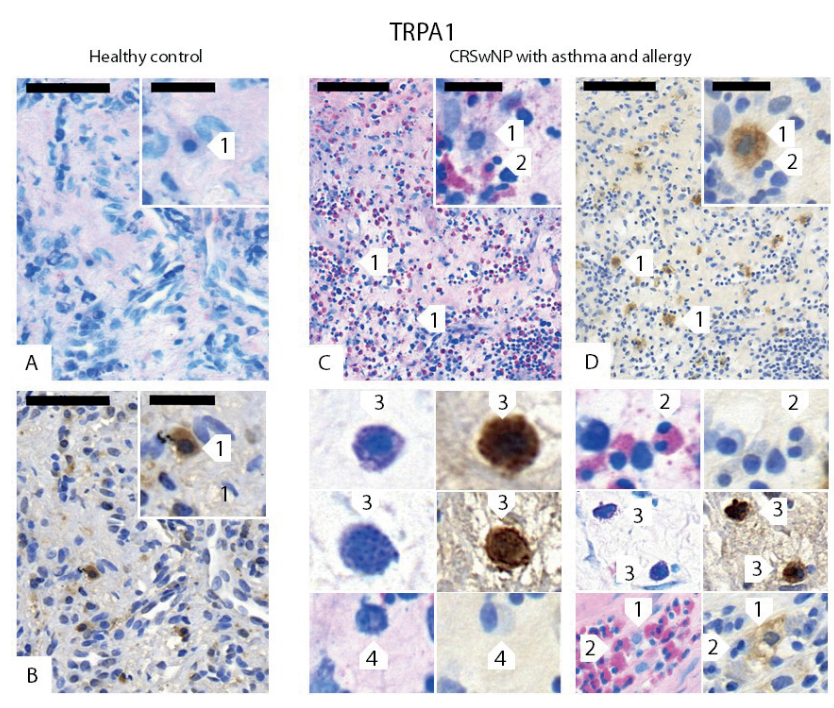

Figure 4. Paired images of Giemsa staining and TRPA 1 specific immunostaining of healthy control $(A, B)$ and CRSwNP patients with asthma and allergy (C, D with blocks of image pairs). A, B: magnification: 400x, scale bar: $50 \mu \mathrm{m}$; inserts: 800x, $20 \mu \mathrm{m}$. C, D: 200x, $100 \mu \mathrm{m}$; inserts: 800x, $20 \mu \mathrm{m} .1$ :TRPA1 positive macrophage; 2 : TRPA1 negative eosinophil granulocyte; 3: TRPA1 positive mast cell; 4: TRPA1 negative plasma cell.

mRNA was similar to mast cell markers in the order of: TAC4 $>$ CD117 > CHM-1 (chymase). TRPA1 demonstrated a highly disparate pattern from all inflammatory markers except IL-8. In a further step of analysis, correlation coefficient $r$ values were calculated between genes (Supplementary Figure 2) with some selected $r$ values displayed in Table 3. TRPV1 mRNA levels correlated positively at a marked level with TAC4 > CD117 > CD79a (plasma B cell receptor), while TRPA1 mRNA correlated negatively with the granulocyte cell surface receptor EMR1 (ADGER1) transcripts.

\section{Discussion}

In tissue samples of asthmatic and allergic nasal polyposus patients, we detected a significant increase in the mast cell and Th2 cell cytokine proteins IL-4 and IL-5 compared to respective non-asthmatic/non-allergic controls. Interleukin-8 (IL-8) levels were significantly higher in all polypous patients compared to control samples, the chemokine being an important attractant for T-cells, basophils and leukocytes ${ }^{(40,41)}$. IFNY protein amount was not significantly altered in CRSwNP patients compared to healthy controls. The cytokine is considered anti-inflammatory since it inhibits isotype switching of B-cells and promotes Th1 activity ${ }^{(42)}$.

We presented immunohistochemical evidence that non-neuronal TRPV1, TRPA1 receptors are expressed in biopsy samples of NP patients. TRPV1 immunostaining was observed on plasma cells and mast cells, mainly in the interglandular space while TRPA1 was enriched on stromal macrophages in NPs. However, 


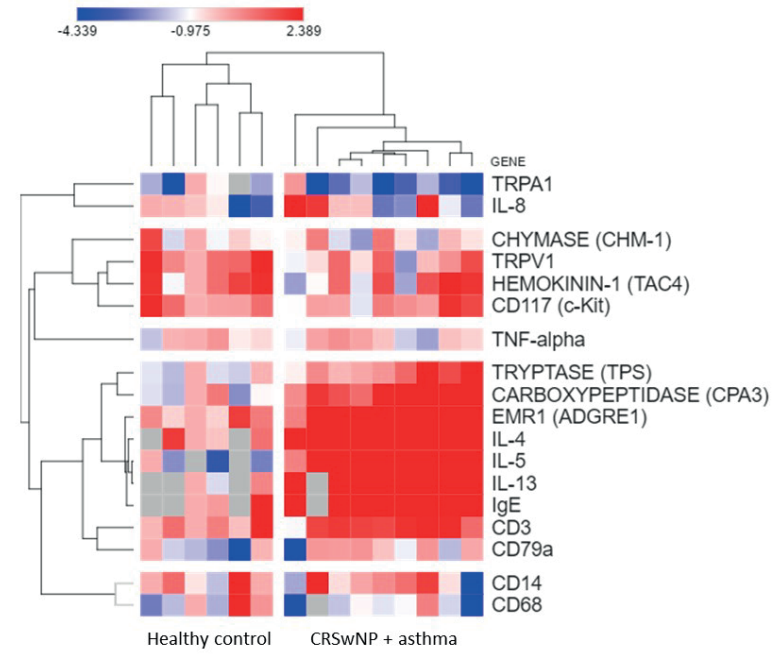

Figure 5. Healthy control and CRSWNP with asthma patients of patient group 2. Transcript data of 17 genes were hierarchically clustered and expression patterns were visualized using a heat map. Rows represent genes (genes names are shownon the right side), columns represent individual healthy control subjects or patients. Relative mRNA levels are represented by a color scale. Dendrograms represent the degree of similarity between gene expression (left side) and patients (top). Shorter dendrogram branches between genes or patients represent larger similarities while longer branches represent larger differences.

we were not able to confirm the presence of TRPA 1 on plasma cells. Mucosal space closely connected to the environment via luminal surface can explain the accumulation of periglandular cells positive for TRPV1, TRPA 1 as chemosensors of environmental pollutants, dust particles and chemicals ${ }^{(28,43)}$. TRPV1 but not TRPA 1 was also expressed by non-plasma cell lymphocytes, and TRPA 1 by fibroblasts. Eosinophils did not express TRPV1, TRPA 1 in agreement with literature data ${ }^{(44)}$.

The presence of TRPV1 on human plasma cells and the extraneuronal expression of TRPA 1 in nasal polyposis were demonstrated for the first time. TRPV1 receptors were previously detected on murine B-cells in lymph node and spleen ${ }^{(45)}$, and in the distal colon in murine colitis ${ }^{(46)}$. There is functional evidence for both TRPV1 and TRPA 1 in the normal human nasal epithelium ${ }^{(8)}$. We have found that TRPV1, TRPA1 mRNA levels were reduced in patients with nasal polyposis when compared to healthy controls. This intriguing result can be explained by at least three, mutually non-exclusive mechanisms.

1. We observed inflammatory cells in healthy control samples of subjects with no known inflammatory upper airway disease ${ }^{(40)}$ which sets the baseline higher for proinflammatory receptor levels. Non-obstructed airways are in constant interaction with the environment via airflow thus healthy volunteers likely exposed to air pollution, dust, etc. cannot be fully regarded as "negative" controls. The detailed mRNA patterns (patient group
Table 3. Correlation between mRNA values in patient group no. 2 , healthy controls and polyp patients with asthma.

\begin{tabular}{|c|c|c|c|}
\hline Gene & $\begin{array}{l}\text { Main express- } \\
\text { ing cell type }\end{array}$ & TRPV1 mRNA & TRPA1 mRNA \\
\hline CD79a & Plasma B cell & 0.2433 & -0.2191 \\
\hline CD117 (C-kit) & Mast cell & 0.5709 & -0.4915 \\
\hline CD68 & Macrophage & -0.01546 & 0.09439 \\
\hline CD14 & Macrophage & -0.1992 & -0.4692 \\
\hline CD3 & T-lymphocyte & -0.02076 & -0.3798 \\
\hline EMR1 (ADGRE1) & $\begin{array}{l}\text { Macrophage, } \\
\text { granulocyte }\end{array}$ & -0.2349 & -0.5362 \\
\hline TAC4 (HK-1) & $\begin{array}{c}\text { Mast cell, } \\
\text { plasma B cell, } \\
\text { macrophage }\end{array}$ & 0.7327 & -0.1405 \\
\hline
\end{tabular}

Correlation coefficient values are displayed. Coefficients with an absolute value of $\geq 0.50$ are highlighted in bold numbers. First column: gene names followed by main expressing cell.

\#2) indeed revealed an individual variability in inflammation markers in our healthy control samples. Alternative anatomical locations have been proposed for harvesting control samples in nasal polyp studies ${ }^{(47,48)}$ but may pose practical and ethical challenges.

2. The polypous tissue is more oedematous and greater in volume compared to the normal nasal mucosa ${ }^{(1)}$. Thus the massive infiltration of inflammatory cells occurs in a larger volume and in a variable distribution. There is also tissue damage, e. g. TRP expressing nasal epithelia is impaired.

3. All patients used INCS according to therapy protocol ${ }^{(35)}$. Intranasal steroids are known to reduce levels of IgE, Th2 cytokines, T-cells, mast cells, eosinophils, but not those of neutrophils, macrophages, IFNy or TNFa ${ }^{(49,50)}$ but there are no data on corticosteroids affecting TRP channels in the nasal mucosa, especially on non-neuronal cells. In a different, neuronal context, data are contradictory whether glucocorticoids can affect TRPV1 channels. Derbenev and colleagues communicated an indirect enhancement of TRPV1 activity by dexamethasone in the rat dorsal motor nucleus of the vagus ${ }^{(51)}$. On the other hand, dexamethasone did not alter TRPV1 mRNA expression in the rat dorsal root ganglia and spinal cord ${ }^{(52)}$. Nevertheless, INCS instillation can be blocked by large polyps and the upper part of the nasal cavity is not reached by a nasal spray therefore distribution of topical solution to the unoperated sinuses is limited ${ }^{(35,53)}$. The polyps in our study were considered intranasal steroid resistant. Furthermore, only subgroups of CRSwNP patients - therefore INCS users - were taken into account in a separate comparison where this variable was statistically controlled. In order to overcome these limitations we chose to investigate 
various inflammatory marker mRNAs in a second group of CRSwNP patients with asthma. We observed a marked coexpression of TRPV 1 and TAC4 as well as other mast cell markers. The TAC4 gene product hemokinin-1 peptide is known to enhance TRPV1 (but not TRPA1) responses ${ }^{(54)}$ proliferation and antibody production of B cells ${ }^{\left({ }^{55}\right)}$ as well as IgE-mediated mast cell inflammatory responses ${ }^{(56)}$.

We showed that extraneuronal TRPV1 but not TRPA 1 mRNA is elevated in NP patients with allergy, especially if combined with asthma that induces more severe symptoms. The eosinophilic inflammatory CRS endotype was present overwhelmingly in our study therefore we suppose that this kind of difference in endotype did not influence our results. Regarding an other endotype classification on the basis of inflammatory profile, our samples demonstrated a dominantly Th2 biased cytokine profile as described previously. This is in agreement with the histopathological reports. Since plasma cells consequently presented TRPV1 but not TRPA1 receptors, this could explain the difference between TRP patterns. TRPV1 presence on plasma B cells is an intriguing new result while the ion channel has been known to be involved in mast cell degranulation and release of serotonin and IL-4 ${ }^{(57-59)}$. Environmental irritants can activate TRPA1 on mast cells and macrophages leading to proinflammatory changes ${ }^{(60)}$.

CRSwNP with asthma is a subgroup of patients whose therapy often fails with high recurrent rates. Enhanced inflammatory processes in these patients lead to local, multiclonal lgE response ${ }^{(61)}$. The prominent function of IgE and IgA producing plasma cells within NP tissue is established, IgE activates mast cells and indirectly eosinophils which in turn enhances inflammation (36). We hypothesize that activation of TRPV1 positive plasma cells in CRS patients with asthma contributes to elevated IgE levels and the more severe symptoms. It can be supposed that TRPV1 antagonism may ameliorate the $\lg \mathrm{E}$ cascade and eventually the symptoms.

Intranasal capsaicin desensitization or denervation can act only on neuronal terminals. It cannot reduce the number of mast cells ${ }^{(20)}$ and can alleviate only certain forms of rhinitis and rhinosinusitis ${ }^{(11,14-20)}$. There are data on capsaicin desensitization reducing symptoms in CRSwNP (35) but not in allergic rhinitis (11) possibly due to lack of impact on non-neuronal (i.e. immune cell) TRPV1 functions. The pharmacological blockade of TRPV1 can influence both non-neuronally and neuronally localized receptors in contrast to capsaicin desensitization that impacts

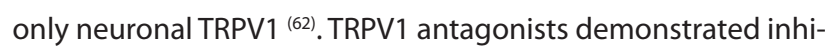
bitory immunologic effects on allergic rhinitis mice models ${ }^{(63)}$. They did not, however, improve allergic rhinitis in patients but formulations with prolonged duration of action are yet to be put to the test ${ }^{(11,64,65)}$. TRPV1 blockers have not been tried in CRSwNP, especially in our complex type with comorbid asthma and allergy. Our results may eventually indicate that TRPV1 antagonism could tackle the more severe symptoms of the subgroup of CRSwNP with asthma and allergy.

\section{Acknowledgements}

E. P. was supported by the OTKA Grant no. NN-114458 and by „János Szentágothai Fellowship" A2-SZJÖ-TOK-13-0149. J. K. was supported by a scholarship from the European Union and the State of Hungary, co-financed by the European Social Fund in the framework of TAMOP-4.2.4.A/2-11/1-2012-0001 'National Excellence Program Apaczai Scholarship'. The research was funded by the „PEPSYS" grant no. GINOP-23.2-15-2016-00050 and the National Brain Research Program 20017-1.2.1-NKP-2017-00002. The present scientific contribution is dedicated to the 650th anniversary of the foundation of the University of Pécs, Hungary.

\section{Authorship contribution}

ET: clinical sample collection, measurements, drafting the paper, discussion; TT: discussion, analysis of immunohistochemistry results; JKneif: immunohistochemistry; AP: immunohistochemistry; KK: analysis of immunohistochemistry results; ZP: clinical sample collection; ÁK: measurements; IG: supervision; JS: supervison; JK: measurements, discussion, drafting the paper; EP: discussion, supervision

\section{Conflict of interest}

None.

\section{References}

1. Han JK. Subclassification of chronic rhinosinusitis. Laryngoscope. 2013; 123: S15-27.

2. Payne SC, Borish L, Steinke JW. Genetics and phenotyping in chronic sinusitis. J Allergy Clin Immunol. 2011; 128: 710-20.

3. Baraniuk JN. Neurogenic mechanisms in rhinosinusitis. Curr Allergy Asthma Rep. 2001; 1: 252-61.

4. Lacroix JS. Chronic rhinosinusitis and neuropeptides. Swiss Med Wkly. 2003; 133: 560-2.

5. Seki N, Shirasaki H, Watanabe K, Kanaizumi E, Konno N, Sato J, et al. Expression and localization of steroid receptors in human nasal mucosa. Acta Otolaryngol. 2009; 124: 958-63.

6. O'Hanlon S, Facer P, Simpson KD, Sandhu $G$, Saleh HA, Anand P. Neuronal markers in allergic rhinitis: expression and correlation with sensory testing. Laryngoscope. 2007; 117: 1519-27.

7. Alenmyr L, Högestätt ED, Zygmunt PM, Greiff L. TRPV1-mediated itch in seasonal allergic rhinitis. Allergy Eur J Allergy Clin Immunol. 2009; 64: 807-10.

8. Alenmyr L, Herrmann A, Högestätt ED,
Greiff L, Zygmunt PM. TRPV1 and TRPA1 stimulation induces MUC5B secretion in the human nasal airway in vivo. Clin Physiol Funct Imaging. 2011; 31: 435-44.

9. Geppetti P, Fusco BM, Marabini S, Maggi CA, Fanciullacci M, Sicuteri F. Secretion, pain and sneezing induced by the application of capsaicin to the nasal mucosa in man. $\mathrm{Br} \mathrm{J}$ Pharmacol. 1988; 93: 509-14.

10. Smith PK, Collins J. Olopatadine $0.6 \%$ nasal spray protects from vasomotor challenge in patients with severe vasomotor rhinitis. Am J Rhinol Allergy. 2011; 25: 149-52. 
11. Fokkens W, Hellings P, Segboer C. Capsaicin for Rhinitis. Curr Allergy Asthma Rep. 2016; 16: 1-5.

12. Van Gool K, Hox V. Non-IgE-Mediated Rhinitis. Curr Otorhinolaryngol Rep. 2015; 3: 170-9.

13. Szolcsányi J. Forty years in capsaicin research for sensory pharmacology and physiology. Neuropeptides. 2004; 38: 37784.

14. Baudoin T, Kalogjera L, Hat J. Capsaicin significantly reduces sinonasal polyps. Acta Otolaryngol. 2000; 120: 307-11.

15. Blom HM, Severijnen LAWFM, Van Rijswijk JB, Mulder PGH, Gerth Van Wijk R, Fokkens WJ. The long-term effects of capsaicin aqueous spray on the nasal mucosa. Clin Exp Allergy. 1998; 28: 1351-8.

16. Sanico AM, Atsuta S, Proud D, Togias A Dose-dependent effects of capsaicin nasal challenge: in vivo evidence of human airway neurogenic inflammation. J Allergy Clin Immunol. 1997; 100: 632-41.

17. Van Rijswijk JB, Boeke EL, Keizer JM, Mulder PGH, Blom HM, Fokkens WJ. Intranasal capsaicin reduces nasal hyperreactivity in idiopathic rhinitis: a double-blind randomized application regimen study. Allergy. 2003; 58: 754-61.

18. Zheng C, Wang Z, Lacroix JS. Effect of intranasal treatment with capsaicin on the recurrence of polyps after polypectomy and ethmoidectomy. Acta Otolaryngol. 2000; 120: 62-6.

19. Cheng J, Yang $X N$, Liu $X$, Zhang SP. Capsaicin for allergic rhinitis in adults. Cochrane Database Syst Rev. 2006:CD004460.

20. Van Gerven L, Alpizar YA, Wouters MM, Hox V, Hauben $E$, Jorissen $M$, et al. Capsaicin treatment reduces nasal hyperreactivity and transient receptor potential cation channel subfamily $\mathrm{V}$, receptor 1 (TRPV1) overexpression in patients with idiopathic rhinitis. J Allergy Clin Immunol. 2014; 133: 1332-1339.e3.

21. Southall MD, Li T ao, Gharibova LS, Pei Y, Nicol GD, Travers JB. Activation of Epidermal Vanilloid Receptor-1 Induces Release of Proinflammatory Mediators in Human Keratinocytes. J Pharmacol Exp Ther. 2003; 304: 217-22

22. Inoue K, Koizumi S, Fuziwara S, Denda S, Inoue K, Denda M. Functional vanilloid receptors in cultured normal human epidermal keratinocytes. Biochem Biophys Res Commun 2002: 291: 124-9.

23. Denda M, Fuziwara S, Inoue K, Denda S, Akamatsu H, Tomitaka A, et al. Immunoreactivity of VR1 on epidermal keratinocyte of human skin. Biochem Biophys Res Commun. 2001; 285: 1250-2.

24. Stander S, Moormann C, Schumacher M Buddenkotte J, Artuc M, Shpacovitch V, et al. Expression of vanilloid receptor subtype 1 in cutaneous sensory nerve fibers, mast cells, and epithelial cells of appendage structures. Exp Dermatol. 2004; 13: 129-39.
25. Basu S, Srivastava P. Immunological role of neuronal receptor vanilloid receptor 1 expressed on dendritic cells. Proc Natl Acad Sci U S A. 2005; 102: 5120-5.

26. Fernandes ES, Fernandes MA, Keeble JE. The functions of TRPA 1 and TRPV1: moving away from sensory nerves. Br J Pharmacol. 2012; 166: 510-21.

27. Bertin S, Aoki-Nonaka Y, de Jong PR, Nohara $\mathrm{LL}, \mathrm{Xu} \mathrm{H}$, Stanwood SR, et al. The ion channel TRPV1 regulates the activation and proinflammatory properties of CD4(+) T cells. Nat Immunol. 2014;

28. Geppetti P, Patacchini R, Nassini R, Materazz S. Cough: The emerging role of the trpa1 channel. Lung. 2010; 188: S63-8.

29. Lee L-Y. TRPA1 ion channels: a gateway to airway irritation and reflex responses induced by inhaled oxidants. J Physiol. 2010; 588: 747-8.

30. Lieberman PL, Smith P, Baroody FM Nonallergic Rhinitis. Immunol Allergy Clin N Am. 2012; 20: 21-30.

31. Bán Á, Marincsák R, Bíró T, Perkecz A, Gömöri É, Sándor K, et al. Upregulation of Transient Receptor Potential Vanilloid Type1 Receptor Expression in Oral Lichen Planus. Neuroimmunomodulation. 2010; 17: 103-8.

32. Kun J, Perkecz A, Knie L, Sétáló G, Tornóczk T, Pintér $E$, et al. TRPA1 receptor is upregulated in human oral lichen planus. Oral Dis. 2016; 23: 189-98.

33. Smith PK, Nilius B. Transient receptor potentials (TRPs) and anaphylaxis. Curr Allergy Asthma Rep. 2013; 13: 93-100.

34. Abdel-Salam OME (Editor). Capsaicin as a Therapeutic Molecule. Vol. 68, Progress in Drug Research. Springer; 2014. 39-77 p.

35. Fokkens W, Lund V, Mullol J. European Position Paper on Rhinosinusitis and Nasal Polyps. Rhinology. 2012;1-136.

36. Akdis CA, Bachert C, Cingi C, Dykewicz MS, Hellings PW, Naclerio RM, et al. Endotypes and phenotypes of chronic rhinosinusitis: A PRACTALL document of the European Academy of Allergy and Clinical Immunology and the American Academy of Allergy, Asthma \& Immunology. J Allergy Clin Immunol. 2013; 131: 1479-1490.

37. Wood N, Bourque K, Donaldson DD, Collins M, Vercelli D, Goldman SJ, et al. IL-21 effects on human IgE production in response to IL-4 or IL-13. Cell Immunol. 2004; 231: 13345.

38. Morpheus [Internet]. Available from: https:// software.broadinstitute.org/morpheus/

39. Langfelder P, Horvath S. Fast R Functions for Robust Correlations and Hierarchica Clustering. J Stat Softw. 2012; 46: 1-17.

40. Ural A, Tezer MS, Yucel A, Atilla H, lleri F. Interleukin-4, interleukin-8 and E-selectin levels in intranasal polyposis patients with and without allergy: a comparative study. J Int Med Res. 2006; 34: 520-4.

41. Yoshifuku K, Matsune S, Ohori J, Sagara Y Fukuiwa T, Kurono Y. IL-4 and TNF-alpha increased the secretion of eotaxin from cultured fibroblasts of nasal polyps with eosinophil infiltration. Rhinology. 2007; 45: 235-41.

42. Lee $\mathrm{CH}$, Rhee CS, Min YG. Cytokine gene expression in nasal polyps. Ann Otol Rhinol Laryngol. 1998; 107: 665-70.

43. Kim D, Baraniuk JN. Sensing the Air Around Us: The Voltage-Gated-Like Ion Channel Family. Rhinitis. 2007;85-92.

44. Håkansson K, Bachert C, Konge L, Thomsen SF, Pedersen AE, Poulsen SS, et al. Airway inflammation in chronic rhinosinusitis with nasal polyps and asthma: The united airways concept further supported. PLoS One. 2015; 10: 1-11.

45. Inada $H$, lida $T$, Tominaga M. Different expression patterns of TRP genes in murine $\mathrm{B}$ and T lymphocytes. Biochem Biophys Res Commun. 2006; 350: 762-7.

46. Kun J, Szitter I, Kemény A, Perkecz A, Kereskai L, Pohóczky K, et al. Upregulation of the transient receptor potential ankyrin 1 ion channel in the inflamed human and mouse colon and its protective roles. PLoS One. 2014; 9: e108164

47. Takabayashi T, Kato A, Peters AT, Suh LA, Carter R, Norton J, et al. Glandular mast cells with distinct phenotype are highly elevated in chronic rhinosinusitis with nasal polyps. J Allergy Clin Immunol. 2012; 130: 410-420. e5.

48. Hulse KE, Norton JE, Suh L, Zhong $Q$, Mahdavinia M, Simon P, et al. Chronic rhinosinusitis with nasal polyps is characterized by B-cell inflammation and EBVinduced protein 2 expression. J Allergy Clin Immunol. 2013; 131: 1075-1083.e7.

49. Kanai N, Denburg J, Jordana M, Dolovich J. Nasal polyp inflammation: Effect of topical nasal steroid. Am J Respir Crit Care Med. 1994; 150: 1094-100.

50. Benson M, Strannegard IL, Wennergren O, Strannegard G. Topical steroid treatment of allergic rhinitis decreases nasal fluid $T(H) 2$ cytokines, eosinophils, eosinophil cationic protein, and IgE but has no significant effect on IFN- $\gamma$, IL-1 $\beta$, TNF- $\alpha$, or neutrophils. J Allergy Clin Immunol. 2000; 106: 307-12.

51. Derbenev A V., Smith BN, Shank S, Akana S, Murayama T. Dexamethasone Rapidly Increases GABA Release in the Dorsal Motor Nucleus of the Vagus via Retrograde Messenger-Mediated Enhancement of TRPV1 Activity. PLoS One. 2013; 8: e70505.

52. Wang $H$, Zhou $M$, Cong $B$, He $P, X u M, N i$ $X$, et al. Transient changes in $\mathrm{P} 2 \mathrm{X} 3$ but not TRPV1 mRNA expression in rat after prenatal exposure to glucocorticoids. Auton Neurosci Basic Clin. 2008; 141: 112-6.

53. Badia L, Lund V. Topical corticosteroids in nasal polyposis. Drugs. 2001; 61: 573-8.

54. Naono-Nakayama R, Sunakawa N, Ikeda T, Nishimori T. Differential effects of substance $P$ or hemokinin-1 on transient receptor potential channels, TRPV1, TRPA 1 and TRPM8, in the rat. Neuropeptides. 2010; 44: 57-61.

55. Wang W, Li Q, Zhang J, Wu H, Yin Y, Ge Q, et al. Hemokinin-1 activates the MAPK path- 
way and enhances B cell proliferation and antibody production. J Immunol. 2010; 184: 3590-7.

56. Sumpter $T L$, Ho $C H$, Pleet $A R$, Tkacheva $O$ a., Shufesky WJ, Rojas-Canales DM, et al. Autocrine hemokinin-1 functions as an endogenous adjuvant for IgE-mediated mast cell inflammatory responses. J Allergy Clin Immunol. 2015; 135: 1019-1030.e8.

57. Freichel M, Almering J, Tsvilovskyy V. The role of TRP proteins in mast cells. Front Immunol. 2012; 3: 1-15.

58. Bíró T, Maurer M, Modarres S, Lewin NE, Brodie C, Acs G, et al. Characterization of functional vanilloid receptors expressed by mast cells. Blood. 1998; 91: 1332-40.

59. Reynier-Rebuffel AM, Mathiau P, Callebert J, Dimitriadou V, Farjaudon N, Kacem K, et al. Substance $\mathrm{P}$, calcitonin gene-related peptide, and capsaicin release serotonin from cerebrovascular mast cells. Am J Physiol. 1994; 267: R1421-9.

60. Parenti A, De Logu F, Geppetti P, Benemei
S. What does evidence indicate about the role of TRP channels in inflammatory and immune cells? Br J Pharmacol. 2015; 173: 953-69.

61. Verbruggen K, Van Cauwenberge P, Bachert C. Anti-lgE for the treatment of allergic rhinitis - and eventually nasal polyps? Int Arch Allergy Immunol. 2009; 148: 87-98.

62. Kun J, Helyes Z, Perkecz A, Bán Á, Polgár B, Szolcsányi J, et al. Effect of Surgical and Chemical Sensory Denervation on Nonneural Expression of the Transient Receptor Potential Vanilloid 1 (TRPV1) Receptors in the Rat. J Mol Neurosci. 2012; 48: 795-803.

63. Samivel R, Kim DW, Son $H R$, Rhee $Y H$, Kim EH, Kim JH, et al. The role of TRPV1 in the $C D 4+T$ cell-mediated inflammatory response of allergic rhinitis. Oncotarget. 2016; 7: 148-60.

64. Alenmyr $L$, Greiff $L$, Andersson M, Sterner O, Zygmunt PM, Högestätt ED. Effect of Mucosal TRPV1 Inhibition in Allergic Rhinitis. Basic Clin Pharmacol Toxicol. 2012; 110:
264-8.

65. Bareille $\mathrm{P}$, Murdoch RD, Denyer J, Bentley J, Smart K, Yarnall K, et al. The effects of a TRPV1 antagonist, SB-705498, in the treatment of seasonal allergic rhinitis. Int J Clin Pharmacol Ther. 2013; 51: 576-84.

\section{J. Kun}

Department of Pharmacology and Pharmacotherapy University of Pécs Medical School H-7624 Pécs

Szigeti út 12.

Hungary

Fax: +36 72 536-218

E-mail: jkun80@gmail.com

\section{Supplementary Information}

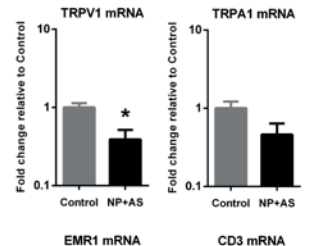

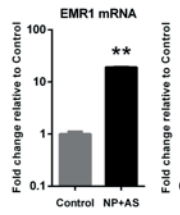
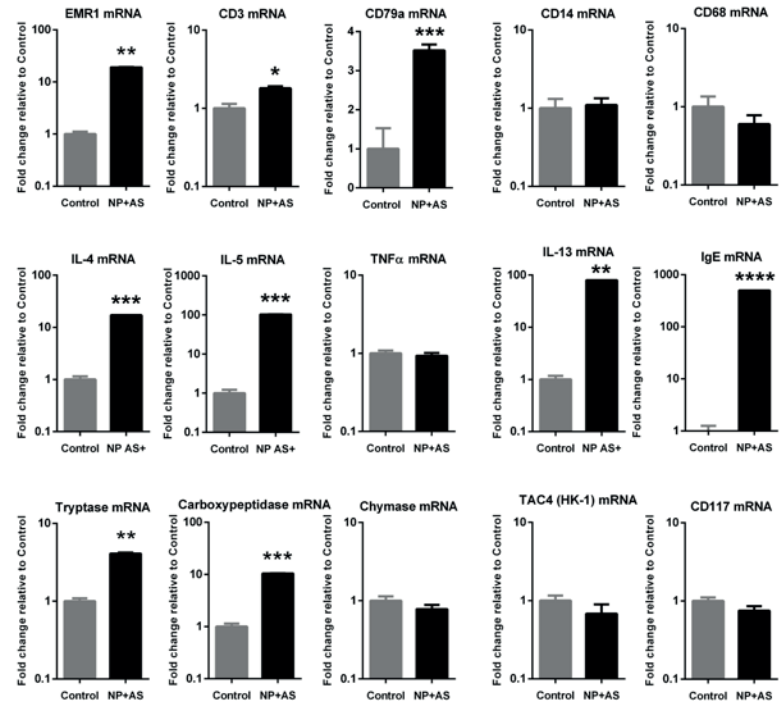

Supplementary Figure 1. Quantitative PCR results for pateint group \#2 (control vs. nasal polyp with asthma). Statistics: unpaired t-test. ${ }^{*} \mathrm{p}<0.05$; ** $p<0.01$; *** $p<0.001 ;{ }^{* * * *} p<0.0001$.

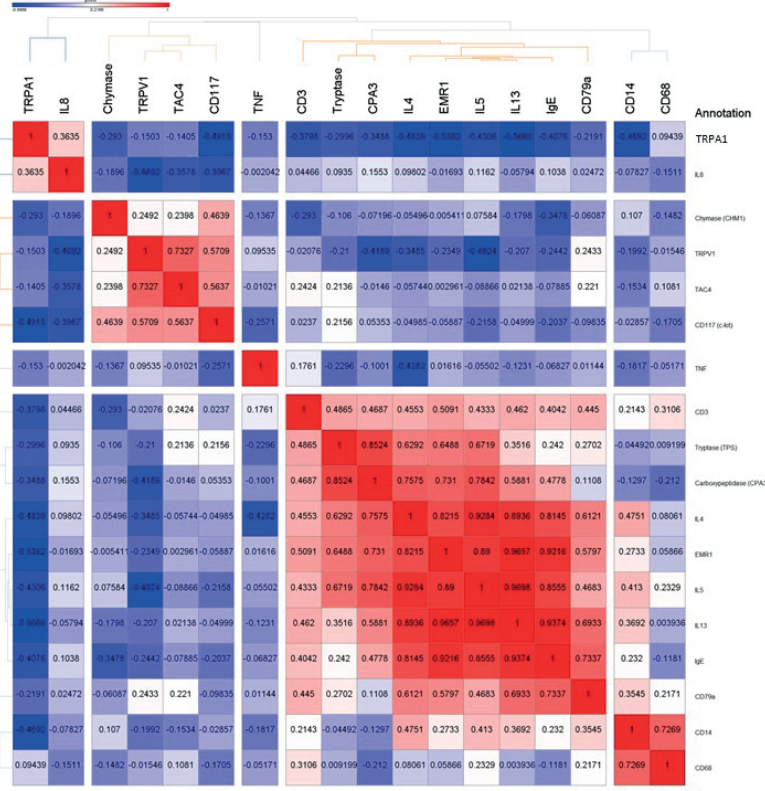

Supplementary Figure 2. Correlation values between mRNA results detected by qPCR in patient group \#2 (control vs. nasal polyp with asth$\mathrm{ma}$ ). Color code: positive correlation is marked with red color, negative correlation is marked with blue color. 


\begin{tabular}{|c|c|c|c|c|}
\hline Gene & Accession number & Assay & Assay location or primer sequence & $\begin{array}{c}\text { Final concentration } \\
\text { used }\end{array}$ \\
\hline GAPDH & $\begin{array}{l}\text { NM_001256799 } \\
\text { NM_002046 }\end{array}$ & Hs02758991 \# & $\begin{array}{l}728 \\
704\end{array}$ & \multirow{4}{*}{$\begin{array}{c}\text { F: } 900 \mathrm{nM} \\
\text { R: } 900 \mathrm{nM} \\
\text { Probe: } 250 \mathrm{nM}\end{array}$} \\
\hline GUSB & NM_000181 & Hs00939627_m1 \# & 1522 & \\
\hline TRPV1 & $\begin{array}{l}\text { NM_018727 NM_080704 } \\
\text { NM_080705 NM_080706 }\end{array}$ & Hs00218912_m1 \# & $\begin{array}{l}1540 \\
1657 \\
1583 \\
1909\end{array}$ & \\
\hline TRPA1 & NM_007332 & Hs00175798_m1 \# & 441 & \\
\hline HPRT1 & NM_000194 & & $\begin{array}{l}\text { F 5'-TTGCTTTCCTTGGTCAGGCA-3' } \\
\text { R 5'-TCAAATCCAACAAAGTCTGGCT-3' }\end{array}$ & $\begin{array}{l}\mathrm{F}: 200 \mathrm{nM} \\
\mathrm{R}: 200 \mathrm{nM}\end{array}$ \\
\hline ACTB & NM_001101 & & $\begin{array}{l}\text { F 5'-GTTGTCGACGACGAGCG-3' } \\
\text { R 5'-GCACAGAGCCTCGCCTT-3' }\end{array}$ & $\begin{array}{l}\mathrm{F}: 500 \mathrm{nM} \\
\mathrm{R}: 500 \mathrm{nM}\end{array}$ \\
\hline CMA1 & $\begin{array}{l}\text { NM_001308083 } \\
\text { NM_001836 }\end{array}$ & & $\begin{array}{l}\text { F 5'-TATGGACGGTCGGATGCAA-3' } \\
\text { R 5'-TTGATCCAGGGCCGGTAAT-3' }\end{array}$ & $\begin{array}{l}\text { F: } 500 \mathrm{nM} \\
\text { R: } 500 \mathrm{nM}\end{array}$ \\
\hline TNF & NM_000594 & & $\begin{array}{l}\text { F 5'-CCCAGGCAGTCAGATCATCTTC-3' } \\
\text { R 5'-AGCTGCCCCTCAGCTTGA-3' }\end{array}$ & $\begin{array}{l}\mathrm{F}: 250 \mathrm{nM} \\
\mathrm{R}: 250 \mathrm{nM}\end{array}$ \\
\hline IFNG & NM_000619 & & $\begin{array}{c}\text { F 5'-ATGTATTGCTTTGCGTTGGACA-3' } \\
\text { R 5'-TCAATAGCAACAAAAAGAAACGAGAT-3' }\end{array}$ & $\begin{array}{l}\mathrm{F}: 250 \mathrm{nM} \\
\mathrm{R}: 250 \mathrm{nM}\end{array}$ \\
\hline $\begin{array}{l}\text { CD117 } \\
\text { (c-Kit) }\end{array}$ & $\begin{array}{l}\text { NM_000222 } \\
\text { NM_001093772 }\end{array}$ & & $\begin{array}{l}\text { F 5'-CGTTCTGCTCCTACTGCTTCG-3' } \\
\text { R 5'-CCCACGCGGACTATTAAGTCT-3' }\end{array}$ & $\begin{array}{l}\mathrm{F}: 250 \mathrm{nM} \\
\mathrm{R}: 250 \mathrm{nM}\end{array}$ \\
\hline $\begin{array}{l}\text { ADGRE1 } \\
\text { (EMR1) }\end{array}$ & $\begin{array}{c}\text { NM_001256255.1 } \\
\text { NM_001256254.1 } \\
\text { NM_001256253.1 } \\
\text { NM_001256252.1 } \\
\text { NM_001974.4 } \\
\text { XM_011527794.1 }\end{array}$ & & $\begin{array}{l}\text { F 5'-CCAGTGTTAATGCCGAAGTCT-3' } \\
\text { R 5'-GTGAACAGGTAAGCCATGACA-3' }\end{array}$ & $\begin{array}{l}\mathrm{F}: 250 \mathrm{nM} \\
\mathrm{R}: 250 \mathrm{nM}\end{array}$ \\
\hline CD3D & $\begin{array}{l}\text { NM_000732.4 } \\
\text { NM_001040651.1 }\end{array}$ & & $\begin{array}{l}\text { F 5'-ACTGGCTACCCTTCTCTCG-3' } \\
\text { R 5'-CCGTTCCCTCTACCCATGTGA-3' }\end{array}$ & $\begin{array}{l}\mathrm{F}: 250 \mathrm{nM} \\
\mathrm{R}: 250 \mathrm{nM}\end{array}$ \\
\hline CD79A & $\begin{array}{l}\text { NM_021601.3 } \\
\text { NM_001783.3 }\end{array}$ & & $\begin{array}{l}\text { F 5'-GGATCATCCTCCTGTTCTGCG-3' } \\
\text { R 5'-TCAGGCCTTCATAAAGGTTTTCA-3' }\end{array}$ & $\begin{array}{l}\mathrm{F}: 250 \mathrm{nM} \\
\mathrm{R}: 250 \mathrm{nM}\end{array}$ \\
\hline CD14 & $\begin{array}{c}\text { NM_000591.3 } \\
\text { NM_001040021.2 } \\
\text { NM_001174104.1 } \\
\text { NM_001174105.1 }\end{array}$ & & $\begin{array}{l}\text { F 5'-ACGCCAGAACCTTGTGAGC-3' } \\
\text { R 5'-GCATGGATCTCCACCTCTACTG-3' }\end{array}$ & $\begin{array}{l}\mathrm{F}: 250 \mathrm{nM} \\
\mathrm{R}: 250 \mathrm{nM}\end{array}$ \\
\hline CD68 & $\begin{array}{l}\text { NM_001251.2 } \\
\text { NM_001040059.1 }\end{array}$ & & $\begin{array}{l}\text { F 5'-ACGCAGCACAGTGGACATTCT-3' } \\
\text { R 5'-GGATCAGGCCGATGATGAGAG-3' }\end{array}$ & $\begin{array}{l}\mathrm{F}: 250 \mathrm{nM} \\
\mathrm{R}: 250 \mathrm{nM}\end{array}$ \\
\hline IL4 & $\begin{array}{l}\text { NM_000589.3 } \\
\text { NM_172348.2 }\end{array}$ & & $\begin{array}{l}\text { F 5'-GCACAAGCAGCTGATCCGAT-3' } \\
\text { R 5'-CAGGAATTCAAGCCCGCC-3' }\end{array}$ & $\begin{array}{l}\mathrm{F}: 250 \mathrm{nM} \\
\mathrm{R}: 250 \mathrm{nM}\end{array}$ \\
\hline IL5 & NM_000879.2 & & $\begin{array}{l}\text { F 5'-CAGTACCCCCTTGCACAGTT-3' } \\
\text { R 5'-CGAACTCTGCTGATAGCCAA-3' }\end{array}$ & $\begin{array}{l}\mathrm{F}: 250 \mathrm{nM} \\
\mathrm{R}: 250 \mathrm{nM}\end{array}$ \\
\hline IL13 & NM_002188.2 & & $\begin{array}{l}\text { F 5'-ACAGCCCTCAGGGAGCTCAT-3' } \\
\text { R 5'-TCAGGTTGATGCTCCATACCA-3' }\end{array}$ & $\begin{array}{l}\mathrm{F}: 250 \mathrm{nM} \\
\mathrm{R}: 250 \mathrm{nM}\end{array}$ \\
\hline $\lg \mathrm{E}$ & NC_018925.2 & & $\begin{array}{c}\text { F 5'- ACCCTGGTCACCGTCTCCTCA-3' } \\
\text { R 5'- CAGGACGACTGTAAGATCTTCACG-3' }\end{array}$ & $\begin{array}{l}\mathrm{F}: 250 \mathrm{nM} \\
\mathrm{R}: 250 \mathrm{nM}\end{array}$ \\
\hline $\begin{array}{l}\text { TPSAB1 } \\
\text { (TRYPTASE) }\end{array}$ & NM_003294.3 & & $\begin{array}{l}\text { F } 5^{\prime} \text {-CTCCCACCGCCATTTCC- } 3^{\prime} \\
\text { R 5'-TTCCCGGCACACAGCAT-3' }\end{array}$ & $\begin{array}{l}\mathrm{F}: 500 \mathrm{nM} \\
\mathrm{R}: 500 \mathrm{nM}\end{array}$ \\
\hline СРАЗ & NM_001870.3 & & $\begin{array}{l}\text { F 5'-AGGATGAAAAACAAGCAGACATCA-3' } \\
\text { R 5'-CAGACTGGATGGCTTGGGATT-3' }\end{array}$ & $\begin{array}{l}\text { F: } 500 \mathrm{nM} \\
\text { R: } 500 \mathrm{nM}\end{array}$ \\
\hline TAC4 (HK-1) & $\begin{array}{c}\text { NM_170685.2 } \\
\text { NM_001077506.1 } \\
\text { NM_001077505.1 } \\
\text { NM_001077504.1 } \\
\text { NM_001077503.1 }\end{array}$ & & $\begin{array}{l}\text { F 5'-TACGGCGAAGCTGTGCATT-3' } \\
\text { R 5'-TCACACAAGGCCCACACTGA-3' }\end{array}$ & $\begin{array}{l}\text { F: } 500 \mathrm{nM} \\
\text { R: } 500 \mathrm{nM}\end{array}$ \\
\hline
\end{tabular}

